\title{
Independence and Management Support: The Advocate for Internal Auditors' Task Performance in Tertiary Institutions
}

\author{
Oyewumi Hassan Kehinde*, Ayoib Che-Ahmad and Oluwatoyin Muse Johnson Popoola
}

Tunku Puteri Intan Safinaz School of Accountancy, College of Business, Universiti Utara Malaysia 06010

UUM Sintok, Kedah, Malaysia

\begin{abstract}
Tertiary institutions in Nigeria are bedevilled with many financial irregularities and deficiencies that make the existence and the task performance (TP) of the internal auditors in the institutions questionable. This study, therefore, empirically examines the influence of independence (IND) and management support (MS) on the TP of internal auditors in the SouthWest tertiary institutions in Nigeria. The study formulates and tests two hypotheses in respect of the relationship between IND and TP in one hand, and MS and TP on the other hand. This study employs a quantitative approach, cross-sectional design, and survey questionnaire in obtaining data from 350 internal auditors in the internal audit departments/units of the universities, polytechnics, and colleges of education in South-West Nigeria. The study records a response rate of sixty percent (60\%). Data are analysed using Statistical Packages for Social Sciences (IBM SPSS) version 22.0, and Partial Least Squares-Structural Equation Modeling (PLS-SEM), version 2.0. The results of the PLS-SEM algorithm and bootstrapping reveal positive significant relationships between IND and TP, and the MS and TP, hence, the two hypotheses are supported. This study is significant and has practical and theoretical implications. It has a policy implication on the government or private proprietors who are owners of tertiary institutions; management and Council who control the institutions, internal auditors who are operators of internal auditing; regulatory authorities that perform oversight function on the institutions, and professional accounting and auditing bodies. The study adds to the body of literature and extends internal audit research to tertiary institutions.
\end{abstract}

Keywords: Independence, Management Support, Internal Auditors, SouthWest Nigeria

JEL Classification: M42. M48. M49

Paper Type: Research Paper

*Corresponding author: E-mail: olanipekunhk@yahoo.com 


\section{INTRODUCTION}

Auditing, internal or external, without independence in principle and practice is not an audit and will not achieve the purpose for which audit is created. In the same coin, the achievement of audit function will be a mirage if not supported by the management. The combination of independence and management support, therefore, appears to be pertinent to the effective internal audit task performance.

Globally, the task of internal auditing has metamorphosed from the traditional role of ticking the box by examining the financial and accounting operations of an organisation to evaluating the entire organisational activities (Algeru, 2011). Al-Twaijry, Brierley, and Gwilliam (2003) state two essential benefits accruable to organisations for having internal audit function. In the first instance, an organisation tends to benefit from the conventional audit leading to prevention and detection of irregularities and fraud, and safeguarding the assets of an organisation. Secondly, the organisation gains from the value audit which has to do with the economy, efficiency, and effectiveness of all operations of the organisation. The main goal of internal audit task, therefore, is to add value to the entire activities of an organisation through the economy, efficiency, and effectiveness.

The Federal Government of Nigeria (2009) introduced reforms in the public sector accounting that culminated into the issuance of Financial Regulations, which require among others the establishment of internal audit department/units in all ministries, departments and agencies (MDAs) of government. The regulation requires the internal audit to conduct one hundred percent pre-audit checks on vouchers. Aside this general framework, the authorities regulating the activities of tertiary institutions comprising National Universities Commission (NUC), National Board for Technical Education (NBTE), National Commission for Colleges of Education (NCCE) have uniform accounting manual that specifies the functions, duties and powers of internal auditors in the institutions. In addition to this, the functions and power of internal audit department are in the uniform audit manual issued by the Committee of Heads of Internal Audit Departments/Units in Nigerian Universities (CHIADINU, 2007), and the audit manual of each institution.

The duties in these regulations and manuals revolve around examining the compliance of the institutions to the internal control system, while the power centres on the unrestricted access to records, information, and people in the organisation at all reasonable time. With all these conferred duties and power, the assumption is that financial accounting sanity will prevail in the Nigerian tertiary institutions. However, the rate of irregularities and fraud in the Nigerian Tertiary Institutions (NTI) calls for concern (Auditor-General for the Federation; 2016; Adetoso, Oladejo, \& Akesinro, 2013; Akpomi, Ugodulunma, \& Nnadi, 2005). This is evidenced by the revelation of many deficiencies pointed out by the AuditorGeneral for the Federation (AGF) in the yearly report of period checks (Auditor-General for the Federation; 2016; 2015; 2009). In the 2016 report, the AGF, in Section 10.05, states:

The sum of N132,500,000.00 (One hundred and thirty-two million, five hundred thousand naira) was paid to the contractor through 3 (three) different payment vouchers. The three (3) payment vouchers were neither pre-audited nor checked by the relevant units before payment, and there was no proper description of work done on the payment vouchers (AGF, 2016, p. 271).

Many of the kind of deficiency, neglect and undermining of internal audit function (Achua \& Alabar, 2014; Akpomi, Ugodulunma \& Nnadi, 2005) were reported in several sections of AGF for 2015, 2013 and 2009. The reports of media on the deficiencies in the 
institutions are likewise many and unpalatable. This, therefore, casts doubt on the task performance of internal auditors in the Nigerian tertiary institutions.

Despite the problem confronting internal audit function, especially in the NTI, and the argument of Al-Twaijry et al. (2003) that the value adding the function of internal audit may not be effective in developing countries, the attention of the researchers to this area seems to be low. Hence, there remains paucity of empirical research in the area. Based on provision of the professional standards, theories, and the call of the prior literature (Oyewumi, Ayoib \& Popoola, 2017, Alzeban \& Gwilliam, 2014; Arena \& Azzone, 2009; Mihret \& Yismaw, 2007), this study, therefore, examines the relationships between independence, management support, and the task performance of internal auditors in the universities, polytechnics, and colleges of education in the South-West Nigeria. The justification for the choice of tertiary institutions in South-West Nigeria is that the region has the highest number of tertiary institutions in Nigeria (Ministry of Education, 2015).

\section{LITERATURE REVIEW}

\subsection{Internal Audit Task Performance}

Many scholars in internal audit field (Enofe et al., 2013; Mihret \& Yismaw, 2007; Sawyer, 1995) believe that internal audit task is not thoroughly done or adequately actualised until all the deficiencies in an organisation are corrected and remain corrected. Therefore, the task performance of internal audit department is essential in order to achieve the purpose for which it is created and add value to the organisation as requested by the Institute of Internal Auditors.

Literature and professional standards lay much emphasis on the importance of task performance. Thus, professional auditing bodies prescribed the way by which auditors will achieve effective task performance. From the professional point of view, the International Standards for Professional Practice of Internal Auditing (ISPPIA, 2012), in Performance Standard 2100, makes it essential for internal auditors to assess and contribute to the enhancement of control process, governance, and risk management of their organisations. Similarly, Standard $2120.1 \mathrm{~A}$ majorly requires internal auditors to assess their organisational exposure to risk; the integrity and reliability level of operational and financial information; quality of programs and operations; and safeguard of the assets of the organisation. The extent to which internal auditors will, therefore, achieve their task performance depends on the degree of functional autonomy and supports given to them by the management.

Literature posits that internal auditors perform their task well when they have the enabling independence and management support. Christopher (2014) examined internal audit functions and how they enhance university governance in Australia. He mailed questionnaire electronically to 35 Chief Audit Executives in 35 universities in Australia and employed a descriptive statistics method for analysing the data. The study found that the existence of internal audit charter in the universities, which specifies the functions, duties, and power of internal auditors, enhanced the task performance of the auditors.

In a similar study on internal audit task in Ethiopian public sector, Mebratu (2015) examined the confronting internal audit from achieving its objectives. The study categorised internal audit task into three comprising governance process role, risk management role, and control function. For internal audit function to achieve its risk management role, the study found that there should be unrestricted access, compliance with professional audit standard, top management support, competent leadership, and formal mandate. For control function, the study indicated that sufficient funding, competent staff, and compliance with professional audit standard are essential. Finally, the study 
found governance process function to be associated with compliance with professional audit standard and competent staff.

Many other studies (Alzeban \& Gwillian, 2014; Abu-Azza, 2012; Cohen \& Sayag, 2010; Mihret \& Yismaw, 2007) have argued that internal need to be independent and enjoy the support of the management to attain effective task performance.

\subsection{Independence}

The accounting and auditing professional bodies consider independence as indispensable for the successful conduct of both internal and external audit activities. Hence, many standards issued by them contain therein a provision for independence. The Institute of Internal Auditor (IIA), in its definition, describes Internal Auditing as an independent function. Therefore, independence is the cornerstone upon which effective task performance lies (Tapang, Bessong, \& Ujah, 2015; Baharud-din et al., 2014; Mihret, James, \& Mula, 2010; Christopher, Sarens, \& Leung, 2009). Auditor's independence is an accepted theory which assumes that an auditor needs immunity to enable him to form an independent opinion on the assets, liabilities, and operations being audited (Okoye, 1998). The Public Sector Internal Audit Standards of UK (2012) and the Attribute Standard 1100 of the International Standards for the Professional Practice of Internal Auditing (ISPPIA) issued by IIA (2012) specify that internal audit activity must be independent. According to the standards, independence is the freedom from conditions that threaten the ability of the internal audit activity to carry out internal audit responsibilities in an unbiased manner. Independence is the state of mind that allows the expression of a conclusion without being influenced by interference that impairs professional judgment, allowing a person to act with integrity, and exercise objectivity and professional scepticism (ANAN, 2014; IFAC, 2014; ICAN, 2009).

The concept of independence has been examined in internal and external auditing literature as influencing the task performance of the auditors. Many scholars regard independence as a cornerstone of internal and external auditing. However, researchers have argued on what constitutes independence, and what can enhance or impair it (e.g., Baharud-din et al., 2014; Mihret et al., 2010; Cohen \& Sayag, 2010; Hass, Abdolmohammadi, \& Burnaby, 2006). Some even argue that Internal Auditor, as an employee of an organisation, may not have the freedom needed to exercise unbiased and independent judgment while discharging his responsibilities (Unegbu \& Kida, 2011; Mihret et al., 2010). This notwithstanding, the consensus in the literature is that the existence of independence in internal audit function will enhance the task performance of the auditor. Chambers and Odar (2015) examined the effect of Internal Auditing on the failure of corporate governance in the financial services sector and regarded Internal Auditing as a gatekeeper that failed in preventing the global financial crisis. The study then explored how Internal Auditing can regain its position as one that can prevent future occurrence of a financial crisis. The study asserts that independence of IA is vital in achieving an effective performance of IA and that of the organisation at large.

Cohen and Sayag (2010) empirically investigated the core determinants of internal audit effectiveness in organisations. The finding of the study revealed that independence has a strong correlation with the effective performance of internal audit function. In a similar study of Ebaid (2011), the status of internal audit task of listed companies in Egypt was considered as less mature because the level of independence of internal auditors was found to be low. Several other studies (Alzeban \& Gwilliam, 2014, Christopher, 2014; Ali et al., 2012; Soh \& Martinov-Bennie 2011; Yee et al., 2007) have indicated that there is a relationship between independence and internal audit function. Based on this discussion, the following hypothesis is formulated: 
H1: There is a positive significant relationship between independence and the task performance of internal auditors in the Nigerian tertiary institutions.

\subsection{Management Support}

Ordinarily, auditees do not like to be audited, hence, will try all they can to prevent, deter, and resist audit (Khosravi, 2012) by challenging or frustrating auditors in the course of discharging their task (Ma'ayan \& Carmeli, 2016: Unegbu \& Kida, 2011). Consequently, auditors, especially internal auditors, need an immunity (Okoye, 1998) against the oppression of auditees in order to effectively and efficiently discharge their responsibility without fear. This immunity can be provided by the management through its support for internal audit activity. The management refers to an individual(s) with the executive responsibility of overseeing the conduct and operations of an entity (Nigerian Standard on Auditing, 2013). In other words, top management comprises the Chief Executive Officer (CEO) and his direct subordinates who are charged with the responsibility of corporate policy (Dong, 2008). The International Standards for the Professional Practice of Internal Auditing (ISPPIA, 2012) recognises the importance of management support in the achievement internal audit task performance and makes provision for how the Chief Audit Executive, that is Head of Audit Department should relate with the management. The success of any arm of an organisation, therefore, depends on the level of support and commitment given by the management, and hence, the management support is critical (Bueno \& Gallego, 2017; Dong, 2008).

The role of the management is widely acknowledged in the literature as having an impact on any successful change in an organisation (Feng \& Zhao, 2014; Islam et al., 2009; Worley \& Doolen, 2006). Management support is, therefore, argued to be an indispensable factor that cannot be underestimated in the actualisation of internal audit task performance (Alzeban \& Gwilliam, 2014; Cohen \& Sayag, 2010). As argued in the literature, management support is one the most critical factors or determinants of success for the conduct of activities in an organisation (Bueno \& Gallego, 2017; Salehi, 2016; Alzeban \& Gwilliam, 2014; Christopher, 2014).

Nigerian tertiary institutions are administratively controlled and coordinated by the top management of the institutions comprising the Vice-Chancellors of Universities, Rectors of Polytechnics, the Provosts of the Colleges of Education who are the CEOs, and other principal officers of the institutions such as the Registrar, Bursar, Librarian, and Director of work (Meeyinikor, Timi-Johnson, \& Chux-Nyechu, 2014). Internal audit departments/units are operating as an arm of the Vice-Chancellor/Rector/Provost's office, and they provide assurance and consulting services to the CEOs of the institutions. The departments/units report their activities to the CEO in accordance with the provisions of Federal Government Financial Regulations (FGFR, 2009) and audit manuals of the institutions. The support of the management can, therefore, be evaluated through the protection and motivation given to the internal auditor by the management in the form of adequate finance, implementation of audit reports and recommendations, training and educational program, financial incentives such as compensation and bonus and other relevant supports (Abu-Azza, 2012).

Several studies in the field of accounting, auditing, information System, marketing among others (Bueno \& Gallego, 2017; Alzeban \& Gwilliam, 2014; Christopher, 2014; Cohen \& Sayag, 2010; Dong, 2008; Ifinedo, 2008) revealed there is a relationship between management support and performance. However, little is empirically known about the impact of management support on the task performance of internal auditors in the Nigerian tertiary institutions. 
In the field of auditing specifically, prior studies provide that there is an association between management support and the task performance of internal auditors. Alzeban and Gwilliam (2014) examined the factors influencing the internal auditors' effective performance in 79 public sector organisations in Saudi Arabia. The findings of the study revealed that there is a significant positive relationship between management support and the effective performance of internal auditors. The study emphasised that the influence of management support on audit effectiveness and performance is so strong that without it, internal auditors will not be sufficiently independent, will have restricted scope of work, inadequate resources, and have limited relationship with other stakeholders.

Similarly, Baharud-din et al. (2014) attributed the success of internal auditors as dependent on the extent of management support. The finding of their study revealed that management support is positively and significantly correlated with internal audit effectiveness. The study found management support as the most influencing factor impacting the effective performance of internal auditors. Other scholars such as Mebratu (2015), Christopher (2014), Cohen and Sayag (2010), and Mihret and Yismaw (2007) established the correlation of management support with internal audit task performance. Hence, the construct is essential in the actualisation of the purpose for which internal audit is created. Arising from these findings from the prior literature, this study formulates the second hypothesis $(\mathrm{H} 2)$ thus:

H2: There is a positive significant relationship between management support and the task performance of internal auditors in the Nigerian tertiary institution

\section{METHODOLOGY}

This study applied a quantitative approach and employed a cross-sectional research design. Data were collected from the respondents at one point in time. The population of this study comprised internal auditors in the internal audit departments of tertiary institutions in South-West Nigeria. Internal auditors, in this population context, refers to all the officers performing core internal audit functions which were on professional and executive cadres in the Audit Department and represented Grade Level six and above. Tertiary institutions in this study also referred to universities, polytechnics and colleges of education approved by the NUC, NBTE, and NCCE.

South West (Nigeria) is one of the geopolitical zones in Nigeria with six states comprising Ekiti, Lagos, Ogun, Ondo, Osun and Oyo states. The zone has a total number of ninety-four (94) tertiary institutions comprising 44 universities, 32 polytechnics, and 18 colleges of education (Ministry of Education, 2015; NUC, 2015; NCCE, 2015: NBTE, 2015) with an estimated population of 940 internal auditors. In line with the minimum sample size requirement suggested by Hair et al. (2014a); Popoola, 2014; Tabachnick and Fidell (2007), Sekaran (2003), and Krejcie and Morgan (1970), the study employed a systematic sampling method in drawing a sample of 350 internal auditors from the institutions.

The measurements for the Task Performance (TP), Independence (IND) and Management Support (MS) were adapted from the previous literature. Specifically, seven (7) items of measurement for the TP were adapted from Zakaria, Selvaraj, and Zakari (2006), and Al-Twaijry, Brierley, and Gwilliam (2003). Similarly, eight (8) items of measurements for Independence (IND) construct were adapted from Alzeban and Gwilliam (2014), while seven (7) items of measurement for Management support (MS) were adapted from Alzeban and Gwilliam (2014).

The study used a 5-point Likert-scale questionnaire ranging from strongly disagree to strongly agree in gathering data about the independent and dependent variables. A scale of one (1) was allocated to strongly disagree; two (2) to disagree; three (3) to neutral; four (4) to agree; and five (5) to strongly agree. The 5-point Liker-scale is preferred for this 
study because of its reliability (Kothari, 2004), ease of grading and mean scored value (Popoola, 2014), and an indication of the respondents' strength view (Kumar, 2011).

In line with the recommendation of the scholars, the survey questionnaire emanating from the adapted measurements were subjected to the review of the experts through content validity, and their comments were noted for the necessary amendment to the survey questionnaire. Ten experts comprising five academics and five professional were carefully selected for the content validity of the questionnaire. The selection of the experts is unique and based on their previous publications in the field of accounting and auditing or their audit professional experience and skills. Subsequently, a pilot study was conducted before the administration of the questionnaire to the targeted respondents. The rationale behind the conduct of pilot test was to determine whether the contents of the measures sufficiently captured the constructs and really what they ought to measure. Based on the suggestion of Cavana, Delahaye \& Sekaran (2001), the questionnaires were administered to a total number of fifty (50) respondents, out which only forty-one (41) returned questionnaires were found usable for analysis.

A total number three hundred and fifty (350) questionnaires were administered to internal auditors in the randomly selected universities, polytechnics, and colleges of education in South West, Nigeria. The respondents were required to signify their level of agreement or disagreement with the items of the constructs.

\section{DATA ANALYSIS}

\subsection{Method of Data Analysis}

The usable data obtained from the respondents were analysed using Statistical Packages for Social Sciences (IBM SPSS) version 22.0, and Partial Least Squares-Structural Equation Modeling (PLS-SEM), version 2.0. The preliminary data input, the screening of the data, the respondents' demographic profile, and constructs' descriptive analysis were done using SPSS. As recommended by the scholars (Hair et al., 2017; Garson, 2016; Hair, Ringle \& Sarstedt, 2011), this study employed PLS-SEM in establishing the relationship between the constructs (TP, IND, and MS) by examining the measurement model (internal consistency reliability, convergent validity and discriminant validity) and structural model (path models - relationship).

The data collected from the respondents were subjected to preliminary screening with the aid of SPSS. The study recorded missing values of less one percent, hence mean substitution was employed in replacing the missing values in line with the recommendation of the scholars. The case of outliers, as recommended by Meyers, Gamst and Guarino (2013), was also tested using Mahalanobis Distance Statistic (D2) and the few items that constituted outliers were deleted. Since the data collected for this study emanated from the same set of respondents (Internal Auditors), the study examined whether there was an issue of Common Method Bias (CMB) that could threaten the conclusion of the study. As suggested by Podsakoff et al. (2003), this study employed Harman's single factor analysis in determining CMB. The outcome of this revealed that common method bias did not constitute a threat to the study. 


\section{RESULTS AND FINDINGS}

\subsection{Response Rate and Construct Descriptive Analysis}

Out of the 350 administered questionnaires, the study found only 210 returned questionnaires usable for further statistical analysis. This represents an effective response rate of sixty percent $(60 \%)$.

The descriptive analysis of the constructs as indicated in Table 1 shows that the Task Performance (TP) recorded the highest mean $(M=4.420 ; S D=0.415)$, while Management Support (MS) recorded the lowest mean ( $M=3.382 ; 0.611)$.

Table 1. Descriptive Analysis of the Constructs

\begin{tabular}{lccccc}
\hline \multicolumn{1}{c}{ Construct } & No & Mean (M) & $\begin{array}{c}\text { Standard } \\
\text { Deviation (SD) }\end{array}$ & Minimum & Maximum \\
\hline Task Performance & 210 & 4.420 & 0.415 & 3 & 5 \\
Independence & 210 & 3.486 & 0.503 & 2 & 5 \\
Management Support & 210 & 3.382 & 0.611 & 1 & 5 \\
\hline
\end{tabular}

\subsection{Demographic Profile of the Respondents}

As contained in Table 2, two-thirds of the respondents were university internal auditors, and a higher proportion $(61.9 \%)$ of them were male. Also, a higher portion of the respondents had First Degree/HND certificate as academic qualification, while more than half $(54.8 \%)$ of them did not have any professional qualification. Lastly, about one-third of the study respondents $(31.4 \%$ ) had work experience range of $6-10$ years, $27.6 \%$ of them had a maximum of five years working experience while the remaining the remaining $41 \%$ had more than ten years audit working experience.

Table 2: Respondents' Profile

\begin{tabular}{clcc}
\hline No. & Demographic Profile/ltem & No of Respondents (N=210) & Valid Percentage (\%) \\
\hline 1 & Institutional Category: & 141 & \\
& University & 46 & 67.1 \\
& Polytechnic & 23 & 21.9 \\
& College of Education & 130 & 11.0 \\
\hline 2 & Gender: & 80 & 61.9 \\
& Male & & 38.1 \\
& Female & 6 & \\
& Academic Qualification: & 144 & 2.9 \\
& OND/NCE & 12 & 68.6 \\
& Degree/HND & 48 & 5.7 \\
& PGD & & 22.9 \\
& Masters & 115 & \\
& Professional Qualification: & 3 & 54.8 \\
& None & 3 & 1.4 \\
& ACCA/CISA & 40 & 1.4 \\
& ACPAN & 49 & 19 \\
& ANAN & & 23.3 \\
& ICAN & 58 & 27.6 \\
& Work Experience: & 66 & 31.4 \\
& 5 year and below & 30 & 14.3 \\
& 6-10 & 25 & 11.9 \\
& 11-15 & 31 & 14.8 \\
\hline
\end{tabular}




\subsection{Evaluation of the Measurement and Structural Models}

\subsubsection{Measurement Model}

This study started the evaluation of PLS-SEM results with the reflective measurement model otherwise known as the path model analysis or outer model. The model dealt with the TP, IND and MS measurements through a set of indicators or items (Sarstedt et al., 2016). The essence of measurement model is to assess the validity and reliability of the constructs. The validity and reliability of the construct were evaluated by the recommendation of Hair et al. (2017). Based on this, three assessments comprising the Internal Consistency (Composite Reliability (CR)); Convergent Validity of the constructs which consists of Indicator Reliability and Average Variance Extracted (AVE); and Discriminant Validity were done.

Table 3. Validity and Reliability Result

\begin{tabular}{ccccccc}
\hline \multirow{2}{*}{$\begin{array}{c}\text { Latent } \\
\text { Construct }\end{array}$} & Indicators & \multicolumn{2}{c}{ Convergent Validity } & $\begin{array}{c}\text { Internal } \\
\text { Consistency } \\
\text { Reliability }\end{array}$ & $\begin{array}{c}\text { Discriminant } \\
\text { Validity }\end{array}$ \\
\cline { 3 - 6 } & & $\begin{array}{c}\text { Outer } \\
\text { Loadings }\end{array}$ & $\begin{array}{c}\text { Indicator } \\
\text { Reliability }\end{array}$ & AVE & $\begin{array}{c}\text { Composite } \\
\text { Reliability (CR) }\end{array}$ & $\begin{array}{c}\text { Fornell-Larcker } \\
\text { Analysis and } \\
\text { Cross Loadings }\end{array}$ \\
\hline \multirow{2}{*}{ IND } & IND6 & 0.912 & 0.832 & 0.764 & 0.866 & Yes \\
& IND7 & 0.835 & 0.697 & & & Yes \\
MS & MS1 & 0.919 & 0.845 & 0.692 & 0.816 & Yes \\
& MS3 & 0.735 & 0.540 & & 0.846 & \\
TP & TP1 & 0.742 & 0.551 & 0.578 & & \\
& TP3 & 0.784 & 0.615 & & & \\
\hline
\end{tabular}

Table 3 presents the summarised result of the measurement model. As regards the convergent validity indicated in the Table, the outer loadings for each of the construct are above the minimum threshold of 0.5 . Specifically, the constructs have a minimum outer loading (0.735) and the maximum outer loading (0.919). Consequently, the indicator reliability of all the items of constructs is above 0.5. As shown in Table 3 , this study recorded the indicator reliability ranging from 0.540 to 0.845 . Also, the AVE of the individual construct is above the required standard of 0.5 (Hair, Ringle \& Sarstedt, 2011). The AVEs of the study ranged from 0.578 (TP) to 0.764 (IND). Based on the statistical results of the outer loading, indicator reliability and AVE, the measures of the three variables (IND, MS, TP) have a great degree of convergent validity (Hair et al., 2017).

\begin{tabular}{|c|c|c|c|c|}
\hline Constructs & Indicators & IND & MS & TP \\
\hline \multirow[t]{2}{*}{ Independence (IND) } & IND6 & 0.912 & 0.122 & 0.285 \\
\hline & IND7 & 0.835 & 0.238 & 0.212 \\
\hline \multirow{2}{*}{ Management Support (MS) } & MS1 & 0.157 & 0.919 & 0.304 \\
\hline & MS3 & 0.182 & 0.735 & 0.177 \\
\hline \multirow[t]{4}{*}{ Task Performance (TP) } & TP1 & 0.266 & 0.230 & 0.742 \\
\hline & TP3 & 0.235 & 0.225 & 0.784 \\
\hline & TP5 & 0.161 & 0.155 & 0.768 \\
\hline & TP6 & 0.194 & 0.283 & 0.747 \\
\hline
\end{tabular}

In relation to the internal consistency reliability, the composite reliability (CR) for IND, MS and TP are higher than the recommended benchmark of 0.708 (Hair et al., 2014a). The study recorded a minimum CR of 0.816 (MS) and the maximum of 0.866 (IND). For discriminant validity, the loadings of each construct are higher than the loadings of the 
associated constructs. As contained in Table 4, the loadings for IND6 (0.912) and IND $(0.835)$ are higher in their domain (IND) than in other constructs. This is also applicable to MS and TP.

Additionally, the study employed Fornell-Larcker criteria in evaluating the discriminant validity. Resulting from this, square roots of the AVE of IND (0.874), MS (0.832), and TP $(0.760)$ in Table 5 are greater than their vertical and horizontal correlation values as suggested by the literature (Hair et al., 2014a; Vinzi et al., 2010).

Table 5. Correlations and Discriminant Validity (Fornell-Larcker Analysis)

\begin{tabular}{lcccc}
\hline Constructs & Indicators & IND & MS & TP \\
\hline Independence & IND & 0.874 & & \\
Management Support & MS & 0.196 & 0.832 & 0.760 \\
Task Performance & TP & 0.289 & 0.302 & \\
\hline
\end{tabular}

Note: The bold figures in diagonals represent the squared average variance extracted (AVE), while other values that are not in bold represent the correlations

\subsubsection{Structural Model}

Having satisfied the requirements for the validity and reliability of the indicators of the constructs in the measurement model (Hair et al., 2014a), the structural model otherwise known as the inner model is dealt with in line with the standard criteria. The structural model dealt with the relationship between the exogenous variables (IND, MS) and the endogenous variable (TP), and its function is to predict the endogenous construct (Hair et al., 2014b).

In order to test the hypotheses set, the structural model was evaluated through bootstrapping. This study bootstrapped with a subsample of 5000 . This was done with a view to determining the t-values and the $p$-values for the constructs. The essence of this is to determine whether the relationships between the independent variables (IND and MS) and the dependent variable (TP) were significant or not. Arising from the bootstrapping process, Figure 1 and Table 6 present the t-values of the IND to TP, and MS to TP. The result indicated in the Figure and Table shows that the t-value of the relationship between IND and TP (beta $=0.239, \mathrm{t}=2.661$ ), while that of MS to TP (beta $=$ $0.256, t=2.524)$. The calculated $t$-values are greater than the standard value of 1.96 , and hence, the relationship between the constructs are positively significant. Therefore, hypotheses $\mathrm{H} 1$ and $\mathrm{H} 2$ are supported.

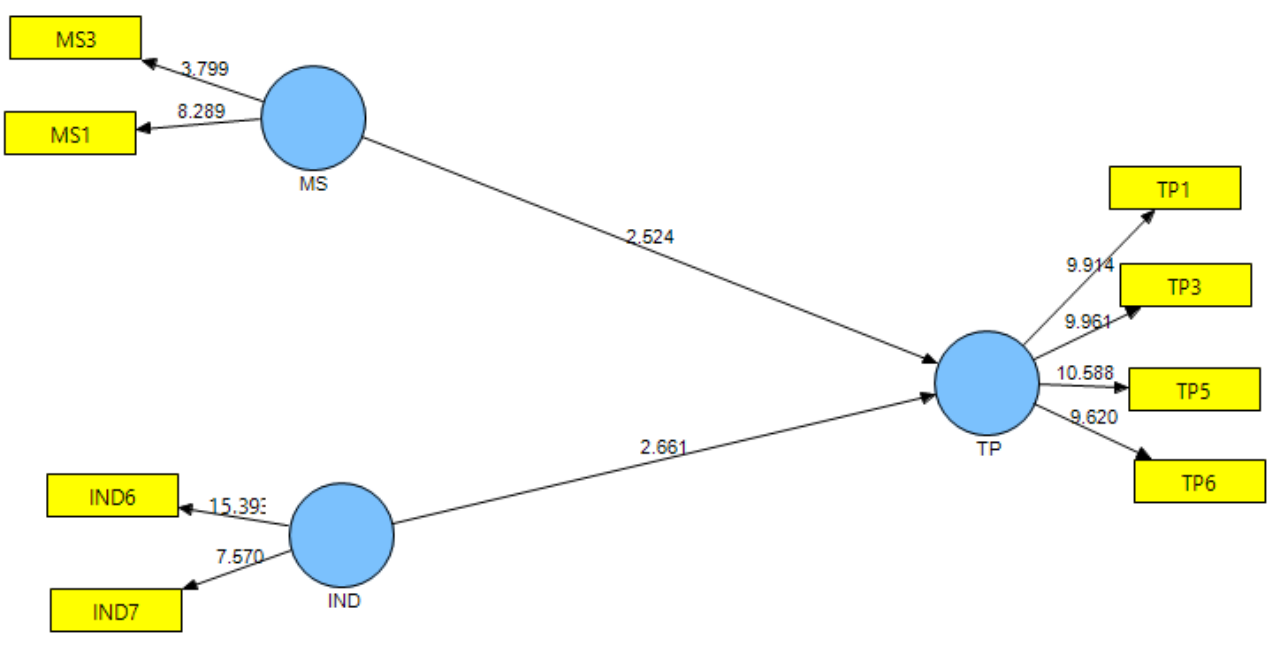

Figure 1. Bootstrapping Result 
Table 6. Relationship between IND, MS and TP

\begin{tabular}{cccccc}
\hline Hypothesis & Relationship & Path Coefficient (b) & Standard Error & t-value & Decision \\
\hline H1 & IND -> TP & 0.239 & 0.090 & 2.661 & Supported \\
H2 & MS -> TP & 0.256 & 0.101 & 2.524 & Supported \\
\hline
\end{tabular}

As contained in Table 6, the two constructs are found to be contributory to the TP (IND t $=2.661$; MS $t=2.524)$, but the contribution of IND is slightly higher. This result is consistent with the extant literature that similarly found independence as crucial in the performance of internal audit function (Alzeban \& Gwilliam, 2014; Mihret et al., 2010; Cohen \& Sayag, 2010). The result also aligns with the conclusion of prior studies that management support is indispensable in the actualisation of effective task performance of internal auditors (Salehi, 2016; Alzeban \& Gwilliam, 2014; Christopher, 2014).

\section{CONCLUSION}

This study contributes to the body of knowledge by empirically examining two key factors influencing the task performance of internal auditors in the educational industry in Nigeria. The study is in response to the call of prior literature for extension of internal audit research to the developing countries. The study investigated the relationship between IND and the TP of internal auditors in the South-West tertiary institutions in Nigeria. It also examined the relationship between MS and the TP of the auditors.

The statistical result of the study confirmed the existence of significant relationships between IND and TP, and MS and TP. In order words, for internal auditors in the institutions to achieve a high level of TP, they need a reasonable level of operational and functional autonomy in the discharge of their responsibility. Also, the auditors need a high level of support from the management for achievement of effective and efficient TP. These two components become essential and a force to be reckoned with if the purpose for which internal audit department and internal auditors are employed is to be achieved.

\section{REFERENCES}

Abu-Azza, W. (2012). Perceived effectiveness of the Internal Audit function in Libya: A qualitative study using Institutional and Marxist theories. PhD thesis submitted to the University of Southern Queensland.

Achua, J. K., \& Alabar, T. T. (2014). Imperatives of marketing internal auditing in Nigerian universities. Procedia-Social and Behavioural Sciences, 164:32-40

Adetoso, J. A., Oladejo, K. S., \& Akesinro, A. S. (2013). Effectiveness of internal auditors in controlling fraud and financial irregularities in private universities in South-West, Nigeria. Research Journal of Finance and Accounting, 4(13).

Akpomi, M. E., Ugodulunwa, C. A., \& Nnadi, M. A. (2005). Strategies for fraud detection and minimization in Nigerian tertiary educational institutions. Journal of Financial Management and Analysis, 18(1).

Algeru, O. I. A. (2011). Perception and evaluation of internal audit in Libyan oil and gas companies. A thesis submitted to the University of Gloucestershire.

Ali, A., Saidin, S. Z., Sahdan, M. H., Rasit, M. H. H., Rahim, M. S., Gloeck, J. D. (2012). Internal Audit in the federal government organizations of Malaysia: The good, the bad and the very ugly? Asian Journal of Business and Governance, 2.

Al-Twaijry, A. A. M., Brierley, J. A., \& Gwilliam, D. R. (2003). The development of Internal audit in Saudi Arabia: an institutional theory perspective. Critical Perspective in Accounting, 14(5).

Alzeban, A., \& Gwilliam, D. (2014). Factors affecting the internal audit effectiveness: A survey of the Saudi public sector. Journal of International Accounting, Auditing and Taxation, 23, 7486.

Association of National Accountants of Nigeria (ANAN). (2014). Handbook of the code of ethics for professional accountants. 
Independence and Management Support: The Advocate for Internal Auditors' Task Performance in Tertiary Institutions

Auditor-General for the Federation of Nigeria (2016). Annual Report of the Auditor-General for the Federation on the accounts of the Federation of Nigeria for the year ended 31st December 2014.

Auditor-General for the Federation of Nigeria (2015). Annual Report of the Auditor-General for the Federation on the accounts of the Federation of Nigeria for the year ended 31st December 2013.

Auditor-General for the Federation of Nigeria (2013). Annual Report of the Auditor-General for the Federation on the accounts of the Federation of Nigeria for the year ended 31st December 2012.

Auditor-General for the Federation of Nigeria (2009). Report of the Auditor-General for the Federation to the national assembly on the accounts of the Federation for the year ended 31st December 2007.

Arena, M., \& Azzone, G. (2009). Identifying organizational drivers of internal Audit effectiveness. International Journal of Auditing, 13, 43-60.

Baharud-din, Z., Shokiyah, A., \& Ibrahim, M. S. (2014). Factors that Contribute to the Effectiveness of Internal Audit in Public Sector. International Proceedings of Economics Development and Research, 70: 126-132.

Bueno, S., \& Gallego, M. D. (2017). Managing top management support in complex information systems projects: An end-user empirical study. Journal of Systems and Information Technology, 19(1/2), 151-164.

Cavana, R. Y., Delahaye, B. I., \& Sekaran. U. (2001). Applied business research: qualitative and quantitative methods. Australia: John Wiley \& Sons Ltd.

Chambers, A. D., \& Odar, M. (2015). A new vision for internal audit. Managerial Auditing Journal, 30(1): 34-55.

Christopher, J. (2014). Internal audit: Does it enhance governance in the Australian Public university sector? Educational Management Administration and Leadership: 1-18.

Christopher, J., Sarens, G., \& Leung, P. (2009). A critical analysis of the independence of the internal audit function: evidence from Australia. Accounting, Auditing \&Accountability Journal, 22(2), 200-220.

Cohen, A., \& Sayag, G. (2010). The effectiveness of internal auditing: An empirical examination of its determinants in Israeli organizations. Australian Accounting Review, 20 (3):54.

Committee of Heads of Internal Audit Departments/Units in Nigerian Universities (CHIADINU). (2007). A manual of uniform internal audit system for Nigerian universities.

Dong, L. (2008). Exploring the impact of top management support of enterprise systems implementations outcomes: Two cases. Business Process Management Journal, 14(2), 204218.

Ebaid, I. E. (2011). Internal Audit function: an exploratory study from Egyptian listed firms. International Journal of Law and Management, 53(2): 108-128.

Enofe, A. O., Mgbame, C. J., Osa-Erhabor, V. E., \& Ehiorobo, A. J. (2013). The role of Internal audit in effective management in public sector. Research Journal of Finance and Accounting, 4(6).

Federal Republic of Nigeria. (2009). Federal Government Financial Regulations. Federal Republic of Nigeria.

Federal Ministry of Education. (2015). Tertiary education. Retrieved from http://www.education.gov.ng/index.php/department/tertiary-education

Feng, T., \& Zhao, G. (2014). Top management support, inter-organizational relationships and external involvement. Industrial Management \& Data Systems, 114(4), 526-549.

Garson, D. (2016). Partial least squares: Regression and structural equation model. G. David Garson and Statistical Associates Publishing

Hair Jr, J. F., \& Hult, G. T. M. (2017). A primer on partial least squares structural equation modeling (PLS-SEM). Sage Publications.

Hair Jr, J. F., Hult, G. T. M., Ringle, C., \& Sarstedt, M. (2014a). A primer on partial least squares structural equation modelling (PLS-SEM). Sage Publications.

Hair Jr, J. F., Sarstedt, M., Hopkins, L., \& G. Kuppelwieser, V. (2014b). Partial least squares structural equation modelling (PLS-SEM) An emerging tool in business research. European Business Review, 26(2), 106-121 
Hair, J. F., Ringle, C. M., \& Sarstedt, M. (2011). PLS-SEM: Indeed a silver bullet. Journal of Marketing Theory and Practice, 19(2), 139-152.

Hass, S., Abdolmohammadi, M. J., \& Burnaby, P. (2006). The Americas literature review on internal auditing. Managerial Auditing Journal, 21(8):835-844

Ifinedo, P. (2008). Impacts of business vision, top management support, and external expertise on ERP success. Business Process Management Journal, 14(4), 551-568.

Institute of Chartered Accountants of Nigeria. (2009). Professional Code of Conduct and Guide for Members.

Institute of Internal Auditors (2012). Supplemental Guidance: The role of auditing in the Public sector. Institute of internal auditors.

International Federation of Accountants (2014). Handbook of the Code of Ethics for Professional Accountants.

Islam, Z., Doshi, J. A., Mahtab, H., \& Ariffin Ahmad, Z. (2009). Team learning, top management support and new product development success. International Journal of Managing Projects in Business, 2(2), 238-260.

ISPPIA. (2012). International Standards for the Professional Practice of Internal Auditing (Standards). The Institute of Internal Auditors.

Khosravi, H. (2012). Auditors and Effective Communication Skills. International Journal of Government Auditing.

Kothari, C. R. (2004). Research Methodology: Methods and techniques. New DelhiNew: Age International.

Kumar, R. (2011). Research Methodology: A step-by-step guide for beginners. SAGE Publications Ltd

Krejcie, R. V., \& Morgan, D. W. (1970). Determining sample size for research activities. Educational and Psychological Measurement, 30: 607-610.

Ma'Ayan, Y., \& Carmeli, A. (2015). Internal Audits as a Source of Ethical Behavior, Efficiency, and Effectiveness in Work Units. Journal of Business Ethics, 1-17.

Mebratu, A. A. (2015). Internal Audit function and its challenges in public sector governance: Empirical evidence from Amhara National Regional State Ethiopia. AshEse Journal of Economics, 1(1): 001-012.

Meenyinikor, C. D. J., Timi-Johnson, T. C., \& Chux-Nyeche, G. C. (2014). Managing Nigerian tertiary educational institutions: a panacea for national security. International Journal of Education Learning and Development, 2 (1): 17-33.

Meyers, L. S., Gamst, G., \& Guarino, A. J. (2013). Applied multivariate research: Design and interpretation. Sage.

Mihret, D. G., James, K., \& Mula, J. M. (2010). Antecedents and organizational performance implications of internal audit effectiveness: some propositions and research agenda. Pacific Accounting Review, 22(3): 224252.

Mihret, D. G., \& Yismaw, A. W. (2007). Internal Audit effectiveness: an Ethiopian public sector case study. Managerial Auditing Journal, 22(5): 470-484

National Board for Technical Education (NBTE). (2015). List of institutions with contact addresses under the purview of NBTE.

National Commission for Colleges of Education (NCCE). (2015). List of Colleges of Education in Nigeria.

National Universities Commission (NUC). (2015). Nigerian Universities. Retrieved from http://nuc.edu.ng/nigerian-univerisities/federal-univeristies/

Nigerian Standards on Auditing (NSA). (2013). Using the work of Internal Auditors. The Institute of Chartered Accountants of Nigeria.

Okoye, A. E. (1998). The quest for proper accountability in the Nigerian Universities and its implications for independence and security of internal Auditor: An overview. The Nigerian Journal of Management Research.

Oyewumi, H. K., Ayoib, B. C., \& Popoola, O. M. J. (2017). Internal auditors' independence and objectivity: regulatory and statutory neglect. International Journal of Economics, Commerce and Management, $V(9), 410-423$. 
Podsakoff, P. M., MacKenzie, S. B., Lee, J. Y., \& Podsakoff, N. P. (2003). Common method biases in behavioural research: a critical review of the literature and recommended remedies. Journal of Applied Psychology, 88(5), 879.

Popoola, O. M. J. (2014). Forensic Accountants, Auditors and Fraud: Capability and competence requirements in the Nigerian public sector. PhD thesis submitted to the Othman Yeop Abdullah Graduate School of Business, Universiti Utara Malaysia

Public Sector Internal Audit Standards (2012). Public sector internal Audit Standards. Applying the IIA International Standards to UK public sector.

Salehi, T. (2016). Investigation Factors Affecting the Effectiveness of Internal Auditors in the Company: Case Study Iran. Review of European Studies, 8(2), 224.

Sarstedt, M., Hair, J. F., Ringle, C. M., Thiele, K. O., \& Gudergan, S. P. (2016). Estimation issues with PLS and CBSEM: Where the bias lies! Journal of Business Research, 69(10), 39984010.

Sawyer, L. B. (1995). An internal audit philosophy. The Internal Auditor, 52(4).

Sekaran, U. (2003). Research methods for business: A skill building approach. John Wiley \& Sons.

Soh, D. S. B., \& Martinov-Bennie, N. (2011). The internal audit function perceptions of internal audit roles, effectiveness and evaluation. Managerial Auditing Journal, 26(7): 605-622.

Tabachnick, B. G., \& Fidell, L. S. (2007). Using multivariate statistics (5th ed.). Pearson.

Tapang, A. T., Bessong, P. K., \& Ujah, P. I. (2015). Management influence and auditor's independence in Nigerian banks. International Journal of Economics, Commerce and Management, III (4).

Unegbu, A. O., \& Kida, M. I. (2011). Effectiveness of internal audit as an instrument of improving public sector management. Journal of Emerging Trends in Economics and Management Sciences, 2(4): 304-309.

Worley, J. M., \& Doolen, T. L. (2006). The role of communication and management support in a lean manufacturing implementation. Management Decision, 44(2), 228-245.

Vinzi, V. E., Chin, W. W., Henseler, J., \& Wang, H. (Eds.). (2010). Handbook of partial least squares: Concepts, methods and applications. Springer Science \& Business Media.

Yee, C. S., Sujan, A., \& James, K. (2007). The perceptions of Singaporean manger Class regarding the role and effectiveness of internal audit in Singapore.

Zakaria, Z., Selvaraj, S. D., \& Zakari, Z. (2006). Internal Auditors: their role in the Institutions of higher education in Malaysia. Managerial Auditing Journal, 21(9): 892-904. 